\title{
ANALISIS KESALAHAN PEMECAHAN MASALAH MATEMATIKA SISWA KELAS XI SMA NEGERI 1 TABANAN
}

\author{
K. I. P. Dewi, I. P. W. Ariawan, I. N. Gita \\ Jurusan Pendidikan Matematika \\ Universitas Pendidikan Ganesha \\ Singaraja, Indonesia
}

e-mail: \{indrapuspita15, wisnab36, inyomangita\}@gmail.com

\begin{abstract}
Abstrak
Penelitian ini bertujuan untuk mengidentifikasi jenis kesalahan dan mendeskripsikan penyebab terjadinya kesalahan pemecahan masalah matematika siswa. Penelitian ini merupakan penelitian kualitatif dengan jenis penelitian studi kasus. Subjek dari penelitian ini adalah siswa yang berasal dari kelas XI MIPA 1, XI MIPA 3, dan XI MIPA 5 SMA Negeri 1 Tabanan tahun ajaran 2018/2019 yang dipilih dengan teknik purposive sampling. Data dikumpulkan menggunakan metode tes dan wawancara mendalam. Instrumen berupa tes pemecahan masalah matematika yang digunakan telah diuji terlebih dahulu validitas dan reliabilitasnya. Analisis data dalam penelitian ini meliputi reduksi data, penyajian data, dan verifikasi data. Jenis kesalahan siswa diklasifikasikan menurut prosedur Newman. Hasil penelitian ini menunjukkan bahwa dalam memecahkan masalah matematika, subjek penelitian melakukan jenis kesalahan; memahami masalah, kesalahan transformasi, kesalahan keterampilan proses, dan kesalahan penulisan jawaban. Jenis kesalahan yang paling banyak dilakukan adalah kesalahan memahami masalah dan kesalahan transformasi, yang disebabkan karena subjek penelitian jarang berlatih mengerjakan soal yang berupa masalah verbal atau memerlukan penafsiran kebahasaan dan soal yang menuntut untuk menyusun model matematika dari suatu masalah, sehingga mereka tidak terbiasa dengan kondisi tersebut. Solusi untuk menghindari atau meminimalisir terjadinya kesalahan tersebut adalah siswa giat berlatih mengerjakan soal berjenis pemecahan masalah, berlatih menjawab pertanyaan yang membutuhkan penafsiran kebahasaan dan pertanyaan yang meminta untuk mengubah suatu masalah ke dalam model matematikanya, serta memeriksa kembali hasil perhitungan dan jawaban yang diperoleh.
\end{abstract}

Kata kunci: analisis kesalahan, pemecahan masalah matematika, prosedur Newman.

\begin{abstract}
This study aims to identify the types of errors and describe the causes of students' errors in mathematical problem solving. This study was a qualitative research by using case study type. The subjects of this study were students of class XI MIPA 1, XI MIPA 3, and XI MIPA 5 SMA Negeri 1 Tabanan in the academic year 2018/2019 and selected by purposive sampling technique. Data was collected using test and in-depth interviews methods. The instrument in the form of a mathematical problem solving test used was tested for its validity and reliability. The data analyze in this study included data reduction, data display, and data verification. The type of student errors are classified according to Newman's procedure. The results showed that in solving mathematical problems, the mistakes made by students are; comprehension error, transformation error, process skills error, and encoding error. The most common type of error is comprehension error and transformation error, which are caused by subjects rarely practice the questions in the form of verbal problems or requiring linguistic interpretations and questions that demand to develop the mathematical model of a problem, so that they are not familiar with these. The solution to avoid or minimize the occurrence of these errors is that the students actively practice working on problem-solving questions, practice answer the questions that require linguistic interpretation and demand to change a problem into the mathematical model, also re-examine all of calculations and answer that have obtained.
\end{abstract}

Keywords: error analyze, mathematical problem solving, Newman procedure. 


\section{PENDAHULUAN}

\begin{tabular}{llr}
\multicolumn{2}{c}{ Pendidikan di Indonesia mengalami } \\
perkembangan & seiring & dengan \\
berkembangnya jaman. Salah satu
\end{tabular} perbaikan di bidang pendidikan dilakukan melalui pengembangan kurikulum. Kurikulum yang kini diterapkan dalam pendidikan di Indonesia adalah kurikulum 2013 yang dirancang dengan berbagai penyempurnaan, antara lain dilakukan penyempurnaan pada standar isi dengan mengurangi materi yang tidak relevan serta memperluas materi yang relevan bagi siswa dan diperkaya dengan kebutuhan siswa untuk berpikir kritis dan analitis (Direktorat Pembinaan SMA, 2017). Melalui pendidikan, pola pikir seseorang dapat diubah agar selalu melakukan inovasi dan perbaikan dalam segala aspek kehidupan. Seperti yang dikemukakan Kostousov dan Kudryavtsev (2017), bahwa pendidikan sebaiknya membekali siswa tidak hanya pada aspek pengetahuan, melainkan untuk menyiapkan mereka dalam memecahkan masalah di kehidupan nyata.

Matematika merupakan salah satu bidang kajian pendidikan yang sering menjadi perhatian. Salah satu aspek penting untuk dikembangkan dalam pembelajaran matematika di sekolah adalah kemampuan pemecahan masalah. Hal ini sesuai dengan lima standar proses dalam pembelajaran matematika menurut NCTM (2000), yaitu problem solving (pemecahan masalah), reasoning and prove (bernalar dan membuktikan), communication (komunikasi), connection (mengaitkan), dan representation (representasi). Selain itu, berdasarkan Permendikbud Nomor 21 Tahun 2016 tentang Standar Isi, mata pelajaran matematika pada sekolah menengah atau SMA salah satunya bertujuan agar siswa memiliki sikap yang tidak mudah menyerah dalam memecahkan masalah, sehingga pembelajaran matematika memiliki peran yang penting bagi siswa agar mampu menyiapkan diri dalam memecahkan masalah di kehidupan nyata (Kemendikbud, 2016).

Kemampuan pemecahan masalah siswa dapat dilatih melalui pemberian soalsoal pemecahan masalah. Lencher (dalam
Wardhani, dkk. 2010) mendeskripsikan masalah matematika sebagai soal matematika yang strategi penyelesaiannya memerlukan pengetahuan, keterampilan dan pemahaman yang telah dipelajari sebelumnya. Menurut Polya (1957) terdapat dua jenis masalah matematika yaitu problem to find and problem to prove. Problem to find (menemukan suatu masalah) bertujuan untuk menemukan, menentukan maupun mendapatkan penyelesaian dari suatu soal yang diberikan dengan memberikan kondisi yang tepat. Sedangkan problem to prove (membuktikan masalah) bertujuan menunjukkan suatu pernyataan yang diberikan benar atau tidak benar dengan suatu prosedur yang didapatkan.

Dalam memecahkan masalah matematika tentunya siswa akan dihadapkan dengan berbagai tantangan, seperti kesulitan dalam memahami masalah, karena masalah yang dihadapi bukanlah suatu masalah yang rutin (sering) dihadapi sebelumnya, sehingga solusi dari masalah tersebut tidak bisa langsung diketahui siswa. Usaha untuk mencari solusi dari suatu masalah agar tidak menjadi masalah lagi adalah usaha pemecahan masalah.

Pemecahan masalah dalam pembelajaran matematika merupakan penggunaan konsep-konsep, prinsip dan keterampilan matematika yang telah dipelajari atau yang telah dimiliki seseorang sebelumnya untuk menyelesaikan suatu masalah non rutin. Pemecahan masalah pada dasarnya merupakan proses yang ditempuh atau dilalui oleh seseorang untuk menyelesaikan masalah yang dihadapinya sehingga masalah tersebut tidak lagi menjadi masalah bagi dirinya.

Memecahkan masalah matematika dapat diartikan sebagai usaha untuk memperoleh solusi dari suatu masalah non rutin menggunakan kemampuan pemecahan masalah yang diperoleh dari pengetahuan, konsep-konsep, prinsipprinsip, dan keterampilan matematika yang dimiliki berdasarkan hasil pembelajaran dan pengalaman sebelumnya. Namun, sering kali siswa tidak terampil atau melakukan kesalahan dalam menyelesaikan soal-soal yang diberikan, sehingga kemampuan 
pemecahan masalah yang dimilikinya tidak berkembang.

Kemampuan siswa di bidang matematika dapat ditunjukkan dari hasil survei Programme for International Student Assessment (PISA) yang diinisiasi oleh Organisation for Economic Co-operation and Development (OECD) atau Organisasi untuk Kerjasama dan Pembangunan Ekonomi. Di mana survei PISA tersebut bertujuan untuk mengevaluasi sistem pendidikan dari 72 negara di seluruh dunia dengan memberikan siswa tes pada mata pelajaran utama seperti membaca, matematika, dan sains. Pencapaian Indonesia di PISA 2015 pada bidang matematika adalah memperoleh skor 386, sementara rata-rata skor OECD adalah 490, dan skor tertinggi diperoleh Singapura yaitu 564 (OECD, 2016). Hasil tersebut dapat menunjukkan bahwa kemampuan pemecahan masalah matematika siswa di Indonesia tergolong rendah, karena pada studi PISA, soal-soal matematika yang diberikan lebih banyak mengukur kemampuan penalaran, pemecahan masalah, dan berargumentasi dibandingkan soal-soal yang mengukur kemampuan teknis baku yang berkaitan dengan ingatan atau perhitungan yang dengan mudah dilakukan siswa.

Permasalahan dalam memecahkan masalah matematika juga dialami di SMA Negeri 1 Tabanan khususnya oleh siswa kelas XI MIPA. Berdasarkan hasil wawancara dengan guru matematika kelas XI MIPA SMA Negeri 1 Tabanan, diperoleh bahwa siswa kelas XI MIPA tahun ajaran 2018/2019 cenderung tidak memiliki motivasi dalam mengerjakan soal berjenis pemecahan masalah dan soal uraian berupa soal cerita. Hal tersebut ditunjukkan dari siswa yang sering melakukan kesalahan dalam menjawab soal uraian pada ulangan harian yang diberikan guru. Selain itu, diperoleh bahwa sebagian besar siswa yang berasal dari kelas XI MIPA 1, MIPA 3, dan MIPA 5 paling sering melakukan kesalahan dalam menjawab soal dibandingkan dengan siswa dari kelas lain. Melalui proses wawancara, guru Matematika kelas XI MIPA mengungkapkan contoh kesalahan yang dilakukan siswa seperti, siswa kurang tepat dalam menuliskan apa yang diketahui dan ditanyakan soal, siswa sering kebingungan menentukan konsep yang harus diterapkan untuk menyelesaikan soal yang diberikan, tidak teliti dalam melakukan proses perhitungan dan kurang tepat dalam menyimpulkan jawaban yang diinginkan oleh soal. Dengan demikian, dapat dikatakan bahwa siswa melakukan kesalahan pada langkah-langkah pemecahan masalah matematika.

Guru sebagai seorang pendidik yang baik tentu akan berusaha membantu siswanya sehingga dapat mencapai kemajuan yang maksimal dalam pembelajaran. Untuk mengetahui apakah bantuan yang diberikan sudah sesuai dengan kebutuhan atau masalah yang dialami siswa, perlu diadakan suatu penilaian. Salah satunya adalah penilaian untuk mengetahui pola kesalahan yang sering muncul dan penyebab siswa melakukan kesalahan dalam memecahkan masalah matematika, sehingga guru dapat membantu siswa untuk memperbaiki atau meminimalisir kesalahan tersebut.

Kesalahan yang dilakukan siswa dalam memecahkan masalah matematika dapat diteliti dan dikaji lebih lanjut mengenai sumber ataupun penyebab siswa melakukan kesalahan tersebut melalui prosedur analisis kesalahan menurut Newman (1977, 1983), yang mengklasifikasikan kesalahan menjadi lima jenis yaitu, reading error (kesalahan membaca), comprehension error (kesalahan memahami masalah), transformation error (kesalahan mentransformasi), process skills error (kesalahan keterampilan proses), dan encoding error (kesalahan penulisan jawaban).

Analisis kesalahan menggunakan prosedur Newman telah dilakukan oleh Rindyana (2013), dengan cara memberikan siswa tes dan melakukan wawancara. Soalsoal matematika yang digunakan pada penelitian tersebut bukanlah soal pemecahan masalah, namun soal matematika yang lebih umum. Lembar jawaban siswa dari tes yang diberikan dianalisis untuk memperoleh jenis kesalahan siswa, dan hasilnya adalah tidak ada siswa yang mampu menjawab dengan 
benar semua soal yang diberikan, siswa paling banyak melakukan kesalahan memahami masalah (comprehension error), selain itu, siswa juga melakukan kesalahan transformasi (transformation error), kesalahan keterampilan proses (process skills error), dan kesalahan penulisan jawaban (encoding error). Dari hasil wawancara diperoleh siswa melakukan kesalahan karena tidak paham dengan apa yang dimaksudkan soal, kurang melakukan latihan menjawab soal yang bervariasi, dan tidak teliti melakukan proses perhitungan.

Hasil yang diperoleh dari pengkajian terhadap kesalahan-kesalahan yang

Tabel 1. Indikator Kesalahan Berdasarkan Prosedur Newman

\begin{tabular}{|c|c|c|}
\hline No & Jenis Kesalahan & Indikator Kesalahan \\
\hline 1. & Membaca (Reading) & $\begin{array}{l}\text { - Tidak dapat mengenali kata-kata atau simbol } \\
\text { matematika yang tertulis pada soal. }\end{array}$ \\
\hline 2. & $\begin{array}{l}\text { Memahami Masalah } \\
\text { (Comprehension) }\end{array}$ & $\begin{array}{l}\text { - Tidak mengetahui/salah menuliskan apa } \\
\text { yang diketahui dari soal. } \\
\text { - Tidak mengetahui/salah menuliskan apa } \\
\text { yang ditanyakan dari soal. }\end{array}$ \\
\hline 3. & $\begin{array}{l}\text { Transformasi } \\
\text { (Transformation) }\end{array}$ & $\begin{array}{l}\text { - Tidak dapat/salah memilih strategi yang } \\
\text { tepat untuk memecahkan masalah. } \\
\text { - Tidak dapat/salah mengubah informasi pada } \\
\text { soal ke dalam kalimat matematika. }\end{array}$ \\
\hline 4. & $\begin{array}{l}\text { Keterampilan Proses } \\
\text { (Process Skills) }\end{array}$ & - Salah dalam melakukan proses perhitungan. \\
\hline 5. & $\begin{array}{l}\text { Penulisan Jawaban } \\
\text { (Encoding) }\end{array}$ & $\begin{array}{l}\text { - Tidak menuliskan jawaban yang sesuai } \\
\text { dengan konteks permasalahan. }\end{array}$ \\
\hline
\end{tabular}

Kesalahan membaca yaitu kesalahan yang dilakukan siswa pada saat membaca soal. Kesalahan membaca terjadi ketika siswa tidak mampu mengenali kata-kata atau simbol matematika yang tertulis dalam soal yang menyebabkan kegagalannya untuk melanjutkan penyelesaian masalah. Dalam prosedur Newman, kesalahan membaca dapat diketahui melalui proses wawancara yang ditandai dengan siswa tidak mengenali atau tidak mengerti dengan kata-kata atau simbol matematika yang tertulis pada soal, dan menyebabkan siswa tidak dapat melanjutkan langkah pemecahan masalah untuk soal tersebut.

Kesalahan memahami masalah adalah kesalahan yang dilakukan siswa setelah ia mampu membaca permasalahan yang ada dalam soal namun tidak mengetahui permasalahan apa yang harus ia selesaikan. Kesalahan memahami masalah terjadi ketika siswa mampu untuk dilakukan siswa dalam memecahkan masalah matematika dapat digunakan sebagai refleksi proses pembelajaran dan sebagai alternatif perbaikan bagi guru dalam pembelajaran untuk meminimalisir atau menghindari kesalahan-kesalahan siswa dalam menyelesaikan soal matematika khususnya soal pemecahan masalah.

Adapun indikator yang dapat digunakan sebagai acuan dalam menentukan jenis kesalahan pemecahan masalah matematika siswa disajikan dalam Tabel 1 berikut. 
diketahui dari hasil pekerjaan dan hasil wawancara yang ditunjukkan dengan siswa salah dalam memilih prosedur/strategi untuk memecahkan masalah atau salah dalam mengubah informasi pada soal ke dalam kalimat matematika.

Kesalahan ketrampilan proses adalah suatu kesalahan yang dilakukan siswa dalam proses perhitungan. Sebuah kesalahan disebut kesalahan keterampilan proses apabila siswa mampu memilih prosedur yang diperlukan untuk menyelesaikan masalah namun ia tak dapat menjalankan prosedur tersebut dengan benar, dengan demikian, siswa yang melakukan kesalahan keterampilan proses dapat diketahui dari hasil pekerjaan dan hasil wawancara yang ditunjukkan ketika siswa salah dalam melakukan perhitungan.

Kesalahan penulisan jawaban adalah kesalahan yang dilakukan karena kurang telitinya siswa dalam menulis jawaban yang diminta oleh soal. Pada tahap ini siswa sudah mampu menyelesaikan permasalahan yang diinginkan oleh soal, namun kurang telitinya siswa dapat menyebabkan berubahnya makna jawaban yang ia tulis. Sebuah kesalahan masih tetap bisa terjadi meskipun siswa telah selesai memecahkan permasalahan matematika, yaitu bahwa siswa salah menuliskan apa yang ia maksudkan, sehingga kesalahan penulisan jawaban dapat diketahui dari hasil pekerjaan dan hasil wawancara yang ditunjukkan ketika siswa tidak menuliskan jawaban akhir yang sesuai dengan konteks permasalahan pada soal.

Hasil yang diperoleh dari pengkajian terhadap kesalahan-kesalahan yang dilakukan siswa dalam memecahkan masalah matematika dapat digunakan sebagai refleksi proses pembelajaran dan sebagai alternatif perbaikan bagi guru dalam pembelajaran untuk meminimalisir atau menghindari kesalahan-kesalahan siswa pemecahan masalah matematika siswa.

Berdasarkan pemaparan di atas, penulis mencoba mengetahui jenis-jenis kesalahan serta mengkaji penyebab siswa melakukan kesalahan pemecahan masalah matematika, sehingga dapat dicari solusi untuk meminimalisir kesalahan tersebut berdasarkan penyebab terjadinya kesalahan.

\section{METODE}

Secara metodologis, penelitian ini merupakan penelitian kualitatif. Pendekatan kualitatif dipilih dalam penelitian ini dengan tujuan agar dapat mengungkap secara lebih cermat mengenai kesalahan pemecahan masalah matematika siswa. Selain itu, dengan pendekatan kualitatif peneliti dapat berkomunikasi secara langsung dengan responden untuk mengetahui hal-hal yang berhubungan dengan kesalahan siswa dalam memecahkan masalah matematika. Jenis penelitian yang digunakan dalam penelitian ini adalah studi kasus.

Studi kasus merupakan penelitian yang dilakukan secara mendalam terhadap kasus tertentu pada sekelompok orang, tempat, maupun peristiwa. Jenis penelitian ini digunakan untuk mendeskripsikan jenis kesalahan dan penyebab terjadinya kesalahan yang dilakukan oleh siswa SMA kelas XI dalam memecahkan masalah matematika, serta dari penyebab kesalahan tersebut dapat diberikan solusi untuk menghindari atau meminimalisisr terjadinya kesalahan.

Jenis data dalam penelitian ini adalah data kualitatif, berupa deskripsi jenis kesalahan dan penyebab terjadinya kesalahan pemecahan masalah matematika siswa. Sumber data dalam penelitian ini berasal dari hasil tes siswa dan wawancara siswa serta guru. Pada penelitian ini, siswa kelas XI MIPA 1, MIPA 3 , dan MIPA 5 yang merupakan siswa yang paling sering melakukan kesalahan dalam memecahkan masalah matematika diberikan tes kemampuan pemecahan masalah matematika dan hasilnya dijadikan bahan untuk analisis kesalahan. Kelas XI MIPA 1 yang terdiri dari 36 siswa, XI MIPA 3 terdiri dari 31 siswa, dan XI MIPA 5 terdiri dari 30 siswa, sehingga terdapat 97 siswa yang diberikan tes kemampuan pemecahan masalah matematika. Hasil tes kemampuan pemecahan masalah matematika kemudian dikoreksi serta diberikan skor dan nilai sesuai dengan rubrik penskoran kemampuan pemecahan masalah matematika. Nilai dari seluruh siswa 
diranking dan dijadikan dasar untuk mengelompokkan siswa secara merata ke dalam tiga kelompok, yaitu kelompok atas, tengah, dan bawah. Dari ketiga kelompok tersebut, dipilih beberapa siswa sebagai subjek penelitian yang dianalisis lembar pekerjaannya untuk memperoleh data jenis kesalahan dan diwawancarai untuk memperoleh data penyebab kesalahan pemecahan masalah matematika.

Penentuan subjek penelitian dilakukan dengan teknik purposive sampling. Lestari (2017: 110) menyebutkan bahwa "Purposive sampling adalah teknik penentuan sampel dengan pertimbangan tertentu". Subjek pada penelitian ini dipilih dengan pertimbangan bahwa kesalahan yang dilakukan dianggap menarik untuk diteliti atau kesalahan yang banyak dilakukan siswa dalam menjawab tes yang diberikan. Dipilih 8 orang subjek penelitian yang dianalisis jenis kesalahan dan penyebab kesalahan dalam memecahkan masalah matematika.

Selain memperoleh data dari subjek penelitian, untuk meningkatkan keabsahan data, juga dilakukan wawancara terhadap satu orang guru matematika yang mengajar di kelas subjek penelitian. Data yang diperoleh dari guru adalah konfirmasi mengenai penyebab siswa melakukan kesalahan yang berkaitan dengan aktivitas siswa dalam proses pembelajaran di kelas, serta aspek-aspek lain seperti cara penyampaian materi oleh guru dan pemberian tugas, sehingga data yang diperoleh dapat dibandingkan untuk memperoleh data yang lebih valid.

Teknik pengumpulan data yang digunakan dalam penelitia ini adalah dengan tes dan wawancara mendalam. Instrumen penelitian merupakan alat bantu bagi peneliti dalam mengumpulkan data. Dalam penelitian kualitatif, peneliti bertindak sebagai instrumen kunci dalam upaya memilih subjek penelitian sebagai sumber data, mengumpulkan data, menganalisis data, menilai kualitas data, menafsirkan data, dan membuat kesimpulan. Selain peneliti yang bertindak sebagai instrumen kunci, dalam penelitian ini digunakan instrumen berupa tes kemampuan pemecahan masalah matematika dan pedoman wawancara. Instrumen yang baik harus memenuhi dua persyaratan penting yaitu valid dan reliabel, sehingga perlu dilakukan uji coba instrumen penelitian.

Instrumen yang perlu diuji coba adalah instrumen dalam bentuk tes. Tes kemampuan pemecahan masalah matematika siswa yang telah disusun diujicobakan dengan tujuan untuk mendapatkan gambaran secara empirik apakah instrumen penelitian berupa tes pemecahan masalah matematika siswa layak digunakan sebagai instrumen. Pertama dilakukan uji pakar/ahli untuk mengetahui validitas isi instrumen. Validitas isi dilakukan oleh dua orang pakar yang merupakan dosen di Jurusan Matematika Undiksha.

Perhitungan validitas isi dilakukan dengan formula Gregory dan dari hasil perhitungan diperoleh koefisien validitas isi tes kemampuan pemecahan masalah yang akan diujicobakan adalah 1,00 yang berarti tes kemampuan yang akan diujicobakan sangat relevan. Selanjutnya, tes kemampuan pemecahan masalah matematika diuji coba pada kelas XI MIPA 1 SMA Negeri 2 Tabanan dengan total soal yang diuji cobakan adalah 6 butir soal dan hasilnya digunakan untuk menghitung validitas dan reliabilitas instrumen tersebut.

"Instrumen disebut valid apabila benar-benar mampu mengukur apa yang semestinya diukur dengan instrumen tersebut" (Candiasa, 2010a:38). Salah satu cara untuk mencari koefisien validitas alat evaluasi yang berbentuk uraian adalah dengan menggunakan koefisien korelasi product-moment dari Carl Pearson (Candiasa, 2010b). Berdasarkan hasil analisis validitas tes uji coba diperoleh 6 butir soal valid. Selanjutnya, butir soal yang valid diuji reliabilitasnya. "Reliabilitas instrumen mengacu pada konsistensi hasil pengukuran yang ditunjukkan oleh instrumen tersebut" (Candiasa, 2010a:41). Untuk menentukan reliabilitas tes digunakan formula koefisien alpha (Alpha Cronbach).

Berdasarkan hasil analisis reliabilitas tes, diperoleh koefisien reliabilitasnya adalah 0,56. Hasil tersebut menunjukkan bahwa tes uji coba kemampuan pemecahan masalah matematika siswa reliabel dengan reliabilitas sedang, 
sehingga soal-soal tersebut layak untuk digunakan. Dari enam soal yang diujicobakan, seluruhnya digunakan untuk instrumen penelitian dalam mengukur kemampuan pemecahan masalah matematika siswa dan hasil jawaban siswa dijadikan bahan analisis kesalahan pemecahan masalah matematika.

Data yang diperoleh dianalisis menggunakan teknik analisis data deskriptif kualitatif Miles dan Huberman (1992). Menurut Miles dan Huberman (dalam Silalahi, 2012: 339), "kegiatan analisis terdiri dari tiga alur kegiatan yang terjadi secara bersamaan, yaitu reduksi data, penyajian data, dan penarikan kesimpulan/verifikasi". Reduksi data merupakan kegiatan merangkum, memilih hal-hal pokok, memfokuskan pada hal-hal yang penting, dan membuang data yang tidak perlu. Penyajian data dilakukan dengan menyusun informasi-informasi yang diperoleh secara sistematis untuk mempermudah dalam menarik kesimpulan. Verifikasi atau menarik kesimpulan dilakukan sejak awal dan dapat berubah bila tidak ditemukan bukti yang kuat yang mendukung pada tahap pengumpulan data berikutnya.

Dalam penelitian kualitatif perlu dilakukan pengecekan keabsahan data sebagai upaya mengobjektifkan hasil temuan. Pengecekan keabsahan data dalam penelitian ini dilakukan melalui triangulasi.

Triangulasi untuk mengecek keabsahan data yang digunakan dalam penelitian ini adalah triangulasi metode dan triangulasi sumber. Triangulasi metode adalah usaha mengecek keabsahan data menggunakan lebih dari satu teknik pengumpulan data, dalam penelitian ini dilakukan pembandingan analisis hasil pekerjaan dengan analisis hasil wawancara subjek penelitian. Sedangkan triangulasi sumber berarti menggali informasi tertentu melalui berbagai sumber berbeda kemudian membandingkan informasi tersebut, yang dalam penelitian ini dilakukan wawancara terhadap guru matematika yang mengajar di kelas subjek penelitian, kemudian data yang diperoleh dibandingkan dengan data yang diperoleh dari subjek penelitian.

Tabel 2. Rangkuman Jenis Kesalahan Subjek Penelitian

\begin{tabular}{llcl}
\hline Subjek Penelitian & \multicolumn{1}{c}{ Kelompok } & Nomor Soal & Jenis Kesalahan \\
\hline $\mathrm{S}_{1}$ & Atas & 1 & Memahami Masalah \\
$\mathrm{S}_{2}$ & Tengah & 2 & Memahami Masalah \\
& & 3 & Penulisan Jawaban \\
$\mathrm{S}_{3}$ & Bawah & 4 & Transformasi \\
& & 1 & Memahami Masalah \\
$\mathrm{S}_{4}$ & Atas & 3 & Transformasi \\
& & 3 & Memahami Masalah \\
$\mathrm{S}_{5}$ & Tengah & 4 & Memahami Masalah \\
& & 1 & Ketrampilan Proses \\
$\mathrm{S}_{6}$ & Bawah & 5 & Transformasi \\
& & 2 & Transformasi \\
$\mathrm{S}_{7}$ & Atas & 6 & Memahami Masalah \\
& & 4 & Memahami Masalah \\
$\mathrm{S}_{8}$ & Tengah & 5 & Memahami Masalah \\
& & 5 & Ketrampilan Proses \\
\hline
\end{tabular}

\section{HASIL DAN PEMBAHASAN}

Data mengenai kemampuan pemecahan masalah matematika siswa diperoleh melalui tes kemampuan pemecahan masalah matematika. Data hasil tes tersebut digunakan untuk mengelompokkan siswa secara merata ke dalam tiga kelompok. Siswa diranking berdasarkan nilai dari tertinggi hingga terendah, kemudian dikelompokkan menjadi kelompok atas, tengah, dan bawah. Hasil tes menunjukkan bahwa ratarata nilai siswa adalah 37,75 dengan nilai maksimum 100. 
Berdasarkan hasil tersebut, dapat dikatakan bahwa kemampuan pemecahan masalah matematika siswa tergolong rendah. Melalui hasil tersebut juga dilihat kesalahan yang dilakukan oleh siswa pada tiap butir soal yang dikerjakan, kesalahan yang dilakukan antara siswa satu dengan yang lain tidaklah sama. Berdasarkan hasil tes, dipilih siswa yang melakukan kesalahan yang dianggap menarik untuk diteliti dan kesalahan yang banyak dilakukan oleh siswa dalam menjawab tes yang diberikan. Analisis kesalahan dilakukan berdasarkan prosedur Newman yang mengklasifikasikan kesalahan menjadi lima jenis kesalahan, yaitu: (1) kesalahan membaca, (2) kesalahan memahami masalah, (3) kesalahan transformasi, (4) kesalahan keterampilan proses, dan (5) kesalahan penulisan jawaban.

Rangkuman hasil analisis jenis kesalahan pemecahan masalah matematika subjek penelitian dapat dilihat pada Tabel 2. Dapat diperhatikan bahwa tidak ada subjek penelitian yang melakukan jenis kesalahan membaca. Jenis kesalahan yang dilakukan oleh seluruh subjek penelitian dari kelompok atas hanya kesalahan memahami masalah, dan seluruh subjek penelitian dari kelompok bawah masing-masing melakukan dua jenis kesalahan yaitu kesalahan memahami masalah serta kesalahan transformasi, meskipun sama-sama melakukan jenis kesalahan memahami masalah, dari proses wawancara diperoleh bahwa penyebab terjadinya kesalahan subjek penelitian dari kelompok atas dan kelompok bawah berbeda. Subjek penelitian dari kelompok atas cenderung melakukan kesalahan memahami masalah karena tidak teliti mengidentifikasi informasi pada soal, sedangkan subjek penelitian dari kelompok bawah melakukan kesalahan memahami masalah karena tidak memahami konsep dari materi. Jenis kesalahan yang dilakukan oleh subjek penelitian dari kelompok tengah lebih bervariasi daripada kelompok atas dan kelompok bawah, begitu pula dengan penyebab terjadinya kesalahan.

Pada penelitian ini tidak terdapat subjek penelitian yang melakukan kesalahan membaca. Meskipun demikian, solusi yang dapat digunakan untuk menghindari kesalahan membaca adalah siswa selalu menambah pengetahuan melalui membaca buku maupun sumber lain untuk mengetahui tentang makna dan cara penyebutan simbol matematika.

Subjek penelitian yang melakukan kesalahan memahami masalah disebabkan karena mereka tidak terbiasa mengerjakan soal yang memerlukan penafsiran kebahasaan, tidak memahami kosep dari materi, dan tidak teliti mengidentifikasi setiap informasi. Solusi yang dapat diberikan adalah siswa hendaknya rajin berlatih menjawab soal yang memerlukan penafsiran kebahasaan, meningkatkan pemahaman konsep, dan memeriksa kembali informasi pada soal.

Subjek penelitian yang melakukan kesalahan transformasi disebabkan karena mereka tidak memahami konsep, jarang berlatih mengerjakan soal yang menuntut untuk mengubah masalah ke dalam model matematikanya, dan tidak teliti mengaitkan informasi pada soal dengan rencana penyelesaian yang akan digunakan. Solusi yang dapat diberikan adalah siswa harus memahami konsep dengan baik melalui pembelajaran dan rajin berlatih mengerjakan soal yang menuntut untuk mengubah masalah ke dalam model matematikanya.

Subjek penelitian yang melakukan kesalahan keterampilan proses disebabkan karena mereka tidak memahami operasi hitung bilangan berpangkat dan tidak teliti melaukan perhitungan. Solusi yang dapat diberikan adalah siswa harus tuntas dalam pembelajaran materi aljabar terutama mengenai operasi hitung yang sering digunakan dan selalu memeriksa kembali proses perhitungan yang telah dibuat.

Subjek penelitian yang melakukan kesalahan penulisan jawaban disebabkan karena siswa tidak teliti memeriksa kembali jawaban yang telah diperoleh, meskipun siswa telah memeriksa jawaban akhir yang didapatkan, hendaknya siswa tidak melupakan konteks permasalahan pada soal, sehingga jawaban yang dibuat sesuai dengan konteks permasalahan.

Berdasarkan kesalahan yang dilakukan oleh subjek penelitian, solusi yang dapat digunakan untuk meminimalisir atau menghindari kesalahan penulisan 
jawaban adalah guru hendaknya menekankan kepada siswa untuk memeriksa kembali hasil pekerjaannya, dan siswa sebaiknya lebih sering berlatih mengerjakan soal pemecahan masalah dan belajar membuat kesimpulan sesuai dengan konteks permasalahan, sehingga siswa terbiasa melakukan langkah tersebut setiap memecahkan masalah matematika.

Kesesuaian antara hasil penelitian ini dengan kajian hasil penelitian sebelumnya oleh Dewi (2014), Rindyana (2013), dan Satiti (2014) adalah jenis kesalahan yang dominan dilakukan siswa adalah kesalahan memahami masalah. Hal tersebut menujukkan bahwa sebagian besar siswa telah melakukan kesalahan dari awal langkah penyelesaian soal atau pemecahan masalah, yang tentunya dapat mempengaruhi langkah-langkah berikutnya. Selain kesalahan memahami masalah, kesalahan transformasi juga menjadi kesalahan yang paling dominan dilakukan oleh subjek penelitian. Penyebab terjadinya kesalahan tersebut adalah subjek penelitian jarang berlatih mengerjakan soal yang menuntut untuk memahami masalah verbal atau memerlukan penafsiran kebahasaan, serta soal yang menuntut untuk menyusun model matematika dari suatu masalah, sehingga mereka tidak terbiasa dengan kondisi tersebut.

\section{SIMPULAN DAN SARAN}

Berdasarkan rumusan masalah, tujuan, hasil analisis, dan pembahasan yang telah diuraikan di depan, dapat disimpulkan bahwa dalam memecahkan masalah matematika, siswa SMA Negeri 1 Tabanan melakukan jenis kesalahan memahami masalah, kesalahan transformasi, kesalahan ketrampilan proses, dan kesalahan penulisan jawaban. Penyebab terjadinya kesalahan adalah siswa tidak teliti mengidentifikasi informasi pada soal, tidak memahami konsep, jarang berlatih mengerjakan soal pemecahan masalah, serta tidak teliti melakukan perhitungan dan menuliskan jawaban. Solusi yang dapat digunakan untuk meminimalisir kesalahan tersebut adalah siswa membaca soal lebih dari satu kali agar tidak ada informasi yang terlewat, belajar memahami konsep, rajin berlatih menjawab soal pemecahan masalah, dan memeriksa kembali hasil perhitungan dan jawaban yang diperoleh.

Berdasarkan hasil penelitian yang telah dilakukan, peneliti melalui tulisan ini menyampaikan saran kepada guru, agar senantiasa melakukan perbaikan dalam proses pembelajaran sebagai upaya untuk meminimalisir kesalahan pemecahan masalah matematika, salah satunya adalah lebih menekankan konsep kepada siswa dan menuntun serta memotivasi siswa untuk berlatih menjawab soal-soal pemecahan masalah matematika. Bagi siswa, hendaknya mengkomunikasikan kesulitan yang dialami dalam proses pembelajaran kepada guru maupun teman yang lebih menguasai materi.

Penelitian ini fokus untuk meneliti kesalahan siswa dalam memecahkan masalah matematika. Peneliti lain yang tertarik dapat meneliti kesalahan pemahaman konsep atau miskonsepsi siswa terhadap salah satu materi dalam pelajaran matematika.

\section{DAFTAR PUSTAKA}

Arikunto, S. 2002. Dasar-Dasar Evaluasi Pendidikan (Edisi Revisi). Jakarta: Bumi Aksara.

Candiasa, I. M. 2010a. Pengujian Instrumen Penelitian Disertai Aplikasi ITEMAN dan BIGSTEP. Singaraja: Universitas Pendidikan Ganesha.

, 2010b. Statistik Univariat dan Bivariat Disertai Aplikasi SPSS. Singaraja: Universitas Pendidikan Ganesha.

Dewi, Emilia S. 2014. Analisis Kesalahan dalam Menyelesaikan Soal Matematika Siswa Kelas X MIA 2 SMA Negeri 2 Singaraja Tahun Ajaran 2013/2014. Singaraja: Universitas Pendidikan Ganesha.

Direktorat Pembinaan SMA Ditjen Pendidikan Dasar dan Menengah. 2017. Modul Penyusunan Soal Higher Order Thinking Skills (HOTS). Jakarta: Kemendikbud Dirjen Guru dan Tenaga Kependidikan. 
Kemendikbud. 2016. Standar Isi Pendidikan

Dasar dan Menengah. Jakarta:

Kemendikbud.

Kostousov, S, dan Kudryavtsev, D. 2017. "Towards a Framework of Using Knowledge Tools for Teaching by Solving Problems in TechnologyEnhanced Learning Environment." International Association for Development of the Information Society.

Lestari, K. E., dan Yudhanegara, M. R. 2017. Penelitian Pendidikan Matematika. Bandung: PT Refika Aditama.

NCTM. 2000. Principles and Standards for School Mathematics. Tersedia di www.nctm.org (diakses pada 20 Oktober 2018).

OECD. 2016. Programme for International Student Assessment (PISA) Results from PISA 2015. Tersedia di www.oecd.org.edu/pisa (diakses pada 22 Oktober 2018.

Polya, G. 1957. How To Solve It. USA: Princenton University Press.

Rindyana, Bunga S. B. 2013. Analisis Kesalahan Siswa dalam Menyelesaikan Soal Cerita Matematika Materi Sistem Persamaan Linear Dua Variabel Berdasarkan Analisis Newman. Malang: Universitas Negeri Malang.

Silalahi, U. 2012. Metode Penelitian Sosial. Bandung: PT Refika Aditama.

Wardhani, S. dkk. 2010. Pembelajaran Kemampuan Pemecahan Masalah Matematika di SMP. Yogyakarta: PPPPTK Matematika.

White, A. L. 2010. "Numeracy, Literacy and Newman's Error Analysis". Jornal of Science and Mathematics Education in Southeast Asia Vol 33. 